\title{
Position of residential buildings in the urban tissue in relation to environmental affect: a review
}

\author{
Sergey Stetsky ${ }^{1}$ and Ekaterina Dorozhkina ${ }^{1, *}$ \\ ${ }^{1}$ Moscow State University of Civil Engineering, 129377, 26 Yaroslavskoye Shosse, Moscow, Russia
}

\begin{abstract}
The article considers the problems, which for the time being become nearly traditional in the field of contemporary residential urban development. The problems discussed depend on the environmental effect of the natural and material surroundings on residential buildings. The influence of noise, light, sun and wind is being discussed. It is noted, that such an affect highly influences the quality of living in residential zones of urban settlements. The structural, architectural and urban planning design solutions are being considered, which increase the quality of indoor and outdoor living in modern cities.
\end{abstract}

\section{Introduction and theoretical background}

Positioning of a residential building within an urban development should be such, that it may obtain the best advantages to its physical location. Such a placement is usually termed as «orientation». The major considerations in orientation of a building or of a dwelling unit are: noise, sunlight and prevailing winds. These factors used to influence the quality of indoor and outdoor environment in the case of urban development of contemporary type and therefore affect the style and quality of living. During the last five decades, such a problems were deeply studied in scientific works of numerous soviet, russian and foreign researchers [1-12].

Hence, the main aim of the authors of this article is to analyse the scientific material spared and to make conclusions, matched to modern state of architectural and urban design.

\section{Case studios}

\subsection{Noise control}

Residential buildings, built near distributor roads or highways are best protected from traffic noise by solid barriers (screens), trees and greenery, placed so, as to prevent noise spread. In addition, accustic privacy in dwellings may be achieved by use a suitable house plans with

\footnotetext{
* Corresponding author: dor-ea@yandex.ru
} 
main living rooms facing away from noise sources and by provision longer distances between residences and road [1-3, 6-7, 9-10] (Figure 1). Proper location and configuration of buildings may add more advantages to the creation of acoustic comfort in residences and courtyards. Say, a random or staggered building layout or a cluster of buildings with no parallel building faces will avoid the problem of multiple reflections of sound waves.

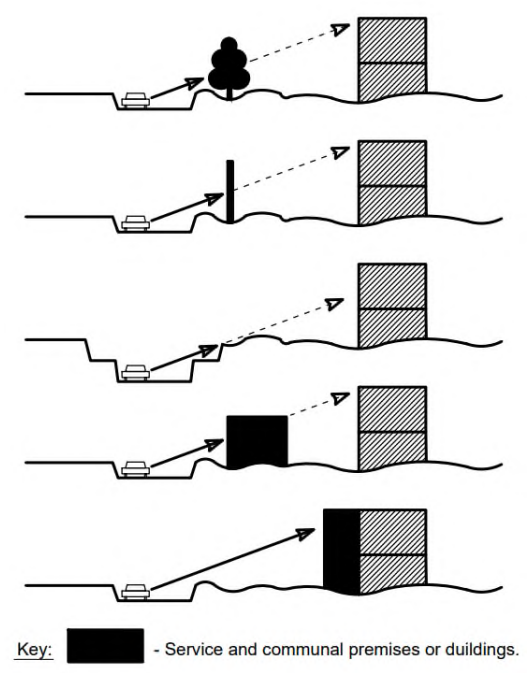

Fig. 1. Main examples of building layout near roads and streets for efficient traffic noise control. A) No obstructions. Noise is limited by placing houses far away from a road; B) Noise protection by trees and greenery; C) Noise protection by solid barriers (screens); D) Noise protection of houses by placing roads in cuttings; E) Noise protection by service or communal buildings placed in between houses and road; F) Noise protection of main rooms in houses by facing them away from the road.

Slightly curved buildings can be beneficial when the curvature is convex relative to the distrirution of noise waves. Semi-enclosed courtyards, faced a noise source, provide areas for multiple reflections and should not be used as outdoor activity areas [1, 2, 6-10] (Figure 2).
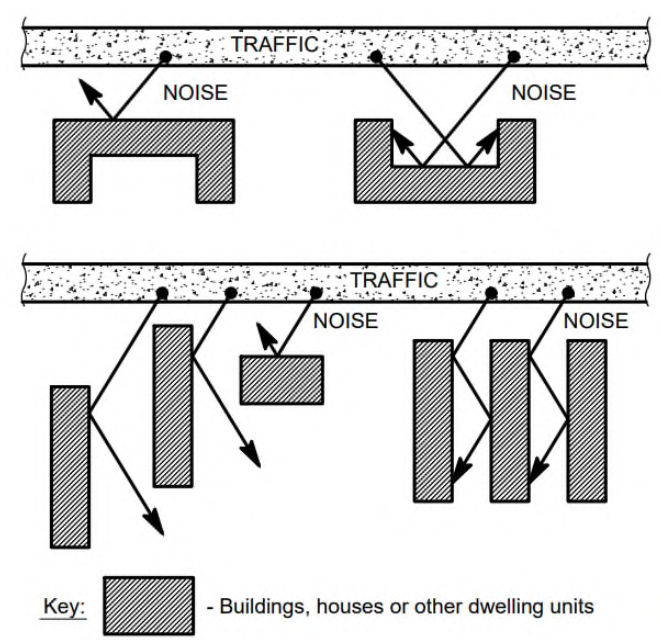

Fig. 2. Main examples of location and configuration of building clusters in order to reduce the effect of sound reflection 


\subsection{Sun and insolation}

The objective of orientation for the sun is to obtain sunlight when it is desirable and to block it out when it is not desired. Due to great variety in climatic conditions it is not difficult to make universal assumptions in this respect. Not ever, it can be generally stated, that for majority of countries with moderate climates it is desirable to have a maximum of sunlight in the wintertime, and have a minimum of it in hot summer [1- 5, 11-12].

Some considerations of the point in question should be generally accepted, i.e.:

- Each apartment or site should get some sun at some time of a day (time of insolation);

- Since people express a variety of desires, it is advisable for dwelling units to have different sun orientation;

- No apartment or sate should be oriented completely toward the north.

The analysis of three main cases, showing different building orientation is quoted in table 1.

Table 1. The availability of insolation of flats and sites in connection with building orientation

\begin{tabular}{|c|c|c|c|}
\hline $\begin{array}{l}\text { The cases } \\
\text { of } \\
\text { orientation }\end{array}$ & $\frac{w}{w_{s}}$ & $\sum_{S E}^{N E}$ & $w \frac{\Delta^{\mathrm{N}}}{\nabla_{\mathrm{S}}}=$ \\
\hline 1 & 2 & 3 & 4 \\
\hline $\begin{array}{l}\text { Description } \\
\text { of cases }\end{array}$ & $\begin{array}{l}\text { Case A } \\
\text { Building with main } \\
\text { axis running } \mathrm{N} \text { to } \mathrm{S} \text {. } \\
\text { Orientation of flats } \mathrm{W} \\
\text { and } \mathrm{E} \\
\end{array}$ & $\begin{array}{l}\text { Case B } \\
\text { Building with main axis } \\
\text { running NW to SE. } \\
\text { Orientation of flats SW } \\
\text { and NE }\end{array}$ & $\begin{array}{l}\frac{\text { Case } \mathrm{C}}{\text { Building with main axis }} \\
\text { running } \mathrm{W} \text { to } \mathrm{E} \text {. Orientation of } \\
\text { flats } \mathrm{N} \text { and } \mathrm{S}\end{array}$ \\
\hline $\begin{array}{l}\text { Insolation } \\
\text { of site }\end{array}$ & $\begin{array}{l}\text { Long shadows cast to } \\
\text { sides of building in } \\
\text { morning and } \\
\text { afternoon hours in } \\
\text { spring and autumn. } \\
\text { Permanently } \\
\text { shadowed area is } \\
\text { located to north of } \\
\text { block in winter. }\end{array}$ & $\begin{array}{l}\text { Shadow pattern varies } \\
\text { between am and pm } \\
\text { hours relatively small. } \\
\text { Permanently shadowed } \\
\text { area in winter. }\end{array}$ & $\begin{array}{l}\text { Serious overshading of ground } \\
\text { to north of the building in } \\
\text { spring and autumn. Large area } \\
\text { of site close to building } \\
\text { resieves no sunlight in winter. }\end{array}$ \\
\hline $\begin{array}{c}\text { Insolation } \\
\text { of flat }\end{array}$ & $\begin{array}{l}\text { Western sunlight will } \\
\text { be present from mid- } \\
\text { afternoon to late } \\
\text { afternoon. During the } \\
\text { summer months the } \\
\text { west sun will be very } \\
\text { intense. Eastern } \\
\text { sunlight will occur } \\
\text { during morning hours } \\
\text { and sun will not be } \\
\text { very intence. Short } \\
\text { period of sunlight in } \\
\text { winter. }\end{array}$ & $\begin{array}{l}\text { South-east and south- } \\
\text { west sun will occur } \\
\text { during morning and } \\
\text { afternoon hours } \\
\text { respectively. North-east } \\
\text { and north-west sun will } \\
\text { occur during early } \\
\text { morning and late } \\
\text { afternoon respectively } \\
\text { and only in summer } \\
\text { months. }\end{array}$ & $\begin{array}{l}\text { No sunlight will be obtained } \\
\text { with a direct north orientation. } \\
\text { For south sunlight will occur } \\
\text { from late morning to early } \\
\text { evening. South orientation is } \\
\text { the best to obtain maximum } \\
\text { sunlight during the day. }\end{array}$ \\
\hline
\end{tabular}




\subsection{Breezes and ventilation}

Buildings, especially in warmer climates, should be oriented towards the prevailing winds. In colder climates, opposite, buildings should be blocked off the cold winds. Where it is possible to have advantages of prevailing breezes, without ruining the requirements for insolation, the long side of a building should be faced towards the breeze. Building location with respect to prevailing winds is an important planning factor, especially during hot or cold seasons [1, 2, 6-9]. The examples of different position of dwellings in respect to climate conditions and a degree of natural ventilation achieved are shown on Figures 3 and 4.

A.

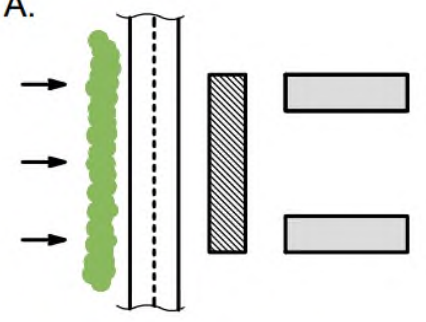

C.

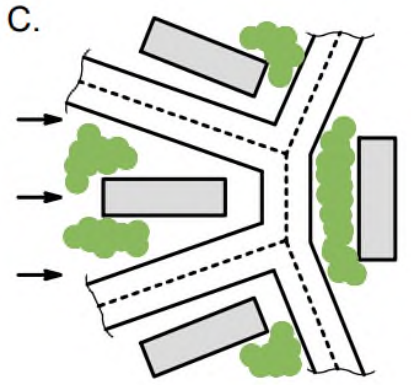

B.
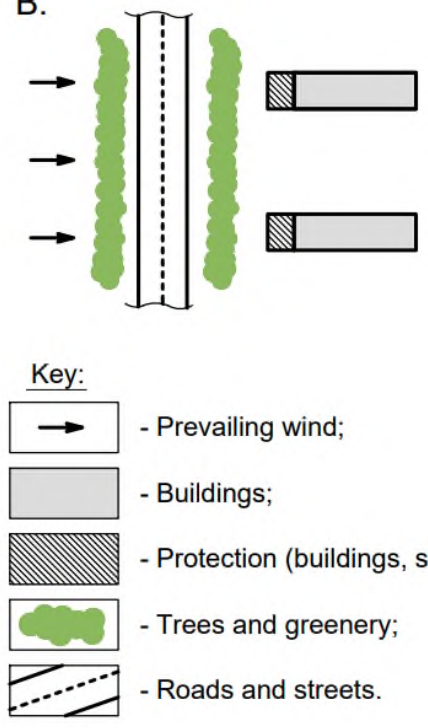

- Prevailing wind;

- Buildings;

- Protection (buildings, structures, etc);

- Trees and greenery;

- Roads and streets.

Fig. 3. Some examples of locality' natural ventilation in different climatic conditions: A) Dry hot climates with sandstorms; cold climates with snowstorms; B) Moderate humid climates with rainfalls and winds; C) Hot humid climates require "fan" development to accelerate wind speed. 
A.

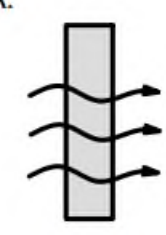

1. $100 \%$

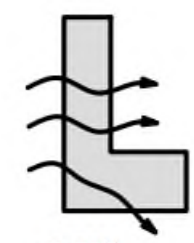

2. $75 \%$

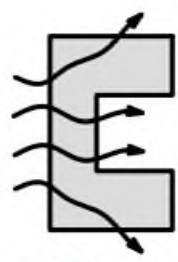

3. $50 \%$

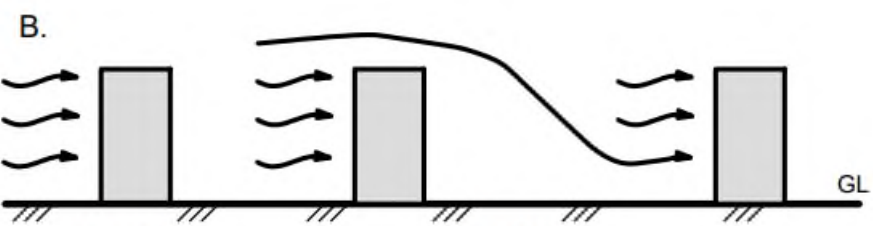

4. $100 \%$

5. $100 \%$

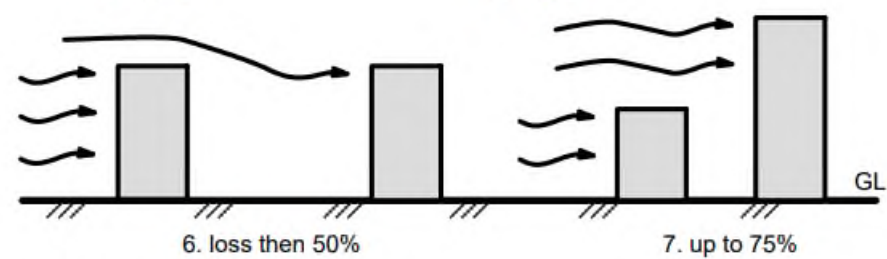

Key:

$\longrightarrow$ - Prevailing winds;

GL - ground level.

Fig. 4. Percentage of ventilation for different building arrangements and position: plans; cross section. 1 - rectangulair buildings; 2 - L-shaped buildings; 3 - U-shaped buildings; 4 - detached buildings, single-standing; 5 - detached buildings in a group; 6 - close-standing buildings of the same height; 7 - close-standing buildings of different height.

\section{Conclusions}

1. As regards to the noise control, the best results can be achieved by combinations of methods, presented on Figure 1. Say, the use of cuttings very logical can be combined with adjacent greenery.

2. Avanability of sunlight to a dwelling should be predicted in respect to surrounding buildings and structures, which may cause obstruction to sunlight, when insolation of dwellings and sites is necessary.

3. Opposite, when solar shading of dwellings and/or sites is desired, the opposite-standing objects may act as means of sun -protection.

4. As a summary, it can be stated, that the best way to achieve an optium orientation of buildings in the urban tissue to satisfy the majorny of environmental requirements is to use a free layout of the urban development.

\section{References}

1. N. M. Gusev, Fundamentals of Building Physics (Moscow, Stroyizdat, 1975)

2. A. K. Soloviev, Environmental Physics (Moscow, ASV Publishers, 2014) 
3. N. V. Obolensky, Architectural Physics (Moscow, Stroyizdat, 1997)

4. Tvarovsky M. Sun in Architecture (Moscow, Stroyizdat, 1997)

5. E. Harkness, M. Mehta, Solar Radiation Control in Buildings (Moscow, Stroyizdat, 1984)

6. V. V. Holshevnikov, A. V. Lugov, A climate of a locality and microclimate of premises (Moscow, ASV Publishers, 2001)

7. K. K. Shevtsov, A Design of Buildings for regions with specific natural and climatic conditions (Moscow, Higher School, 1986)

8. S. V. Stetsky, A. D. Serov, The specifics of comfortable microclimate creation in office buildings for climatic conditions of Near East Countries, Industrial and Civil Construction, 12 (2017)

9. B. Steck, European practice in the integration of lighting, air-conditioning and acoustics in offices, Lighting Research and Technology, 1(1) (1969)

10. S. V. Stetsky, A. I. Gerasimov, Noise protection of civil buildings enveloping structures in big cities of countries with hot climate, Roofing and insulating materials, 1 (2009)

11. Solar shading for low-energy buildings. A report of European Solar-Shading Organization Brussel, Belgium (2012)

12. Undestanding overheating - where to start? An introduction for house builders and designers (Milton Keynes, Great Britain, NHBC Foundation, 2012) 